\title{
工業用純チタニウムのクリープ性についで
}

$$
\text { 山本俊二** 湯河透林八木芳 郎** }
$$

\section{The Creep Properties of Commercial Pure Titanium}

by

\section{Syunji Yamamoto, Toru Yugawa and Yosiro YagI}

(Kobe Steel Works Co., Ltd.)

Synopsis :

Creep rupture properties have been invertigated on the vacuum annealed forged bar of commercially pure titanium KS-70. They were prepared by a consumable electroce double melting method within the temperature range from 200 to $800^{\circ} \mathrm{F}$ (93 to $427^{\circ} \mathrm{C}$ ). (have been investigated.) The results are summerized as follows: (1) In the temperature range from 400 to $600^{\circ} \mathrm{F}$ (204 to $316^{\circ} \mathrm{C}$ ) the temperature graph of creep rupture strength is indicated by an extremely gentle slope, compared with that of short time tensile strength. (2) The causes of this indication are possibly considered to be the strain hardening, the precipitation hardening influenced by foreign matters of extremely small amount in test material and so on, but they must under go a further study so as to be made decidedly clear. (3) However, it is confirmed by the investigation on hardness and by the analysis that hardening phenomena by oxidation did not occur on the occasion.

\section{1. 緒言}

チタニウムの特色の一つは, 軽い上に強らといらと とであるをたとえば，ある種のチタニウム合金なステ ンレス鋼に比して，その抗張力一密度比が，かふり高 温まですぐれている。 それゆえ, 航空機の機体材料, 高速回転体の構造材料, ある々はさらに, 超音速航空 機やヂェット機関の材料として, 最も有望視され, 一 部はすでにこれらの目的て使用されている。

このよらな材料で，使用上最も必要な性質の一つは， 使用温度に和けるクリープ強度であるが, 今回はその 一環として，当社製工業用純チタニウムのクリーブ性 に関して行った実験の結果について報告する。

\section{2. 試験 材}

試験材として, 当社製工業用純チタニウム KS -70材 を選び, らわゆる消耗電極式再溶解法により, $200 \mathrm{~kg}$ $(290 \mathrm{~mm} \phi \times 590 \mathrm{~mm})$ 鋳塊を溶製し， $20 \mathrm{~mm}$ 丸棒に鍛 伸後 JIS 規格 4 号引張試験片および Fig. 1, Fig. 2 亿 示したどときクリープ破断試験片および高温引張試験

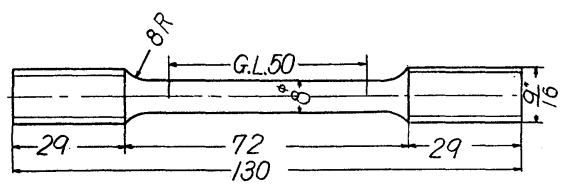

Fig. 1. Creep rupture specimen.

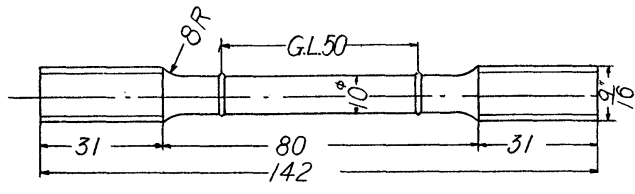

Fig. 2. High temperature short time tensile specimen.

片に機械加工し, $700^{\circ} \mathrm{C} \cdot 1 \mathrm{Hr}$ 真空焼鈍を行って供試 した．との化学成分かよび常温機械的性質を Table 1 に示す。

\section{3. 試 験 方 法}

前述の真空暁鈍した試験材につき，常温和よび 200 $-800^{\circ} \mathrm{F}\left(93-427^{\circ} \mathrm{C}\right)$ 高温短時間引張試験ならどにク リープ破断試験前後の硬度および顕微鏡組織を調べ， そのクリープ特性を求めた。

高温短時間引張試験 (引張速度 $3 \mathrm{~mm} / \mathrm{min}$.) の場合 の伸び測定は，Fig. 2 亿示してあるどとき標点間の凸 起部に適当な伸び測定具を取り付け，乙れれ取り付け てある白金板上の刻みの動をを炬壁の空を通してマイ クロスコープで 1/1000 mm まで読み取る方法で行っ た.

クリープ破断試験は Fig. 1 亿示しそごとを試験片を

* 原稿受付 昭和32年6月14日, 昭和32年5月10日第6斯総会で詊演 ** 株式会社神戸製鋼所神戸研究部(替助員) 
Table 1. Chemical composition and tensile properties (Heat treatment : $700^{\circ} \mathrm{C} \mathrm{hr}$. vacuum annealing)

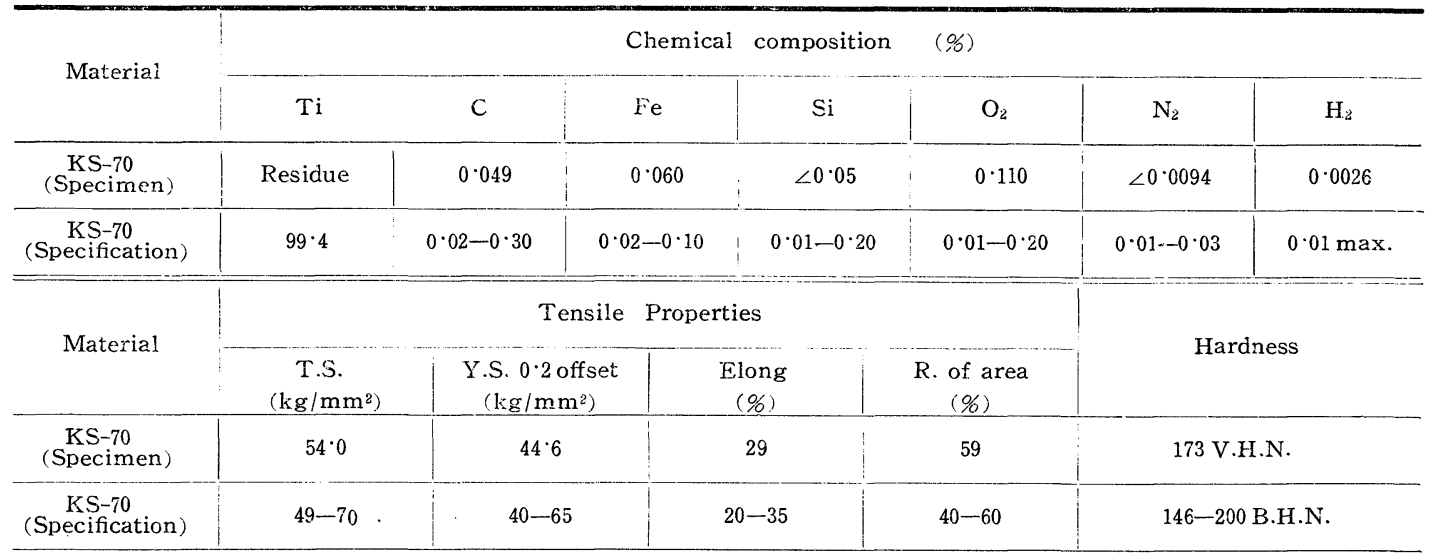

用々，3トンクリープ兼クリープ破断試験機にて行な レ，伸びはプルロッドの動きを $1 / 160 \mathrm{~mm}$ ダイヤルゲ ージにて測定した。試験温度は 200，400，6C0および $800^{\circ} \mathrm{F}\left(93,204,316\right.$ および $\left.427^{\circ} \mathrm{C}\right)$ の 4 温度とし， 各温度で $2 \sim 3$ 筬の適当な荷重を選び, 破断するまで の件びを測定してクリープ破断曲線を求めた。

\section{4. 試 験 結 果}

Fig. 3 亿常温, 200,400, 600 および $800^{\circ} \mathrm{F}$ (93, 204，316 および $427^{\circ} \mathrm{C}$ ) における短時間引張試験の 結果得られそ耐力, 抗張力, 件び, 絞り秥よび弾性率 を走した。乙の図から,本チタ二ウム材は $400-600^{\circ} \mathrm{F}$ $\left(204-316^{\circ} \mathrm{C}\right)$ の間で伸びに最高を生ずると同時に， 抗張力, 耐力などの下がりが, この温度範畔で, やゃ

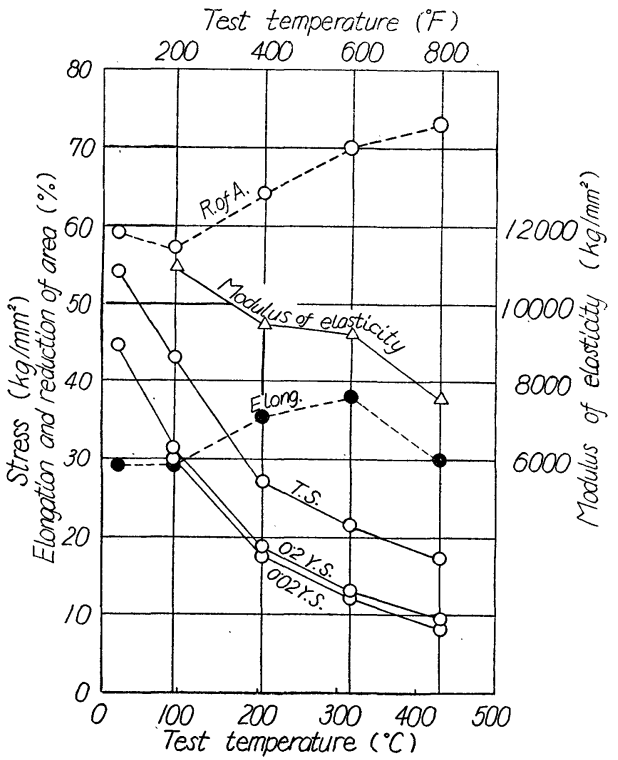

Fig. 3. High temperature short time tensile properties.
Table 2. Creep rupture test results.

\begin{tabular}{|c|c|c|c|c|c|}
\hline $\begin{array}{l}\text { Test } \\
\text { tempe- } \\
\text { rature } \\
\left({ }^{\circ} \mathrm{F}\left({ }^{\circ} \mathrm{C}\right)\right. \\
\end{array}$ & $\begin{array}{c}\text { Test } \\
\text { stress } \\
\left(\mathrm{kg} / \mathrm{mm}^{2}\right)\end{array}$ & $\begin{array}{l}\text { Min. } \\
\text { creep } \\
\text { rate } \\
\text { (\%/hr.) }\end{array}$ & $\begin{array}{c}\text { Rupture } \\
\text { time } \\
\text { (hrs.) }\end{array}$ & \begin{tabular}{|c|} 
Elonga- \\
tion atter \\
rupture \\
$(\%)$
\end{tabular} & $\begin{array}{c}\text { R.of area } \\
\text { after } \\
\text { rupture } \\
(\%)\end{array}$ \\
\hline \multirow{3}{*}{$\begin{array}{l}200 \\
(93)\end{array}$} & $35 \cdot 0$ & $6 \cdot 7$ & $2 \cdot 7$ & 36 & 57 \\
\hline & $50 \cdot 0$ & 0.24 & $89 \cdot 3$ & 39 & 57 \\
\hline & $28 \cdot 0$ & 0.005 & 550.0 stop & - & - \\
\hline \multirow{5}{*}{$\begin{array}{c}400 \\
(204)\end{array}$} & $25 \cdot 3$ & $9 \cdot 4$ & 0.5 & 50 & 63 \\
\hline & $23 \cdot 0$ & $1 \cdot 04$ & $19 \cdot 5$ & 41 & 66 \\
\hline & $22 \cdot 3$ & 0.023 & $132 \cdot 4$ & 35 & 63 \\
\hline & $22 \cdot 0$ & - & 320.0 stop & - & - \\
\hline & $21 \cdot 0$ & - & 430.0 stop & - & - \\
\hline \multirow{4}{*}{$\begin{array}{c}600 \\
(316)\end{array}$} & $20 \cdot 3$ & 60.0 & 0.1 & 38 & 70 \\
\hline & $20^{\circ} 0$ & $34 \cdot 8$ & 0.2 & 26 & ô8 \\
\hline & $19 \cdot 5$ & - & $340^{\circ} 0$ stop & - & - \\
\hline & $19 \cdot 0$ & - & 200.0 stop & - & - \\
\hline \multirow{3}{*}{$\begin{array}{c}800 \\
(427)\end{array}$} & $17 \cdot 0$ & $0 \cdot 14$ & $23 \cdot 6$ & 27 & 82 \\
\hline & $14 \cdot 0$ & 0.045 & $102 \cdot 2$ & 22 & 85 \\
\hline & $12 \cdot 0$ & 0.017 & $601 \cdot 6$ & 52 & 82 \\
\hline
\end{tabular}

ゆるやかになる傾向が認められた。 Table 2 は 200, 400,600 および $800^{\circ} \mathrm{F}\left(93,204,316\right.$ 和よび $\left.427^{\circ} \mathrm{C}\right)$ の各温度に就けるクリープ破断試験の結果で，とのら ら最小クリープ速度はFig. 4 に示したクリープ破断曲 線により求めたものである。

Fig. 4 の各温度に晾けるクリープ破断曲線から次の 傾向が認められる。すなわち，試験時間内に和いて， $200^{\circ} \mathrm{F}\left(93^{\circ} \mathrm{C}\right)$ では，第一期クリープがをわめて長く， $400^{\circ} \mathrm{F}\left(204^{\circ} \mathrm{C}\right)$ および $600^{\circ} \mathrm{F}\left(316^{\circ} \mathrm{C}\right)$ では, 第一期ク リープがをわめて短かく，第二期クリープが長く， $800^{\circ} \mathrm{F}\left(427^{\circ} \mathrm{C}\right)$ では，第一期抋よび第二期クリープが 短かく，第三期クリープがきわめて長い.

Fig. 5 および Fig. 6 は, Table. 2 および Fig. 4 


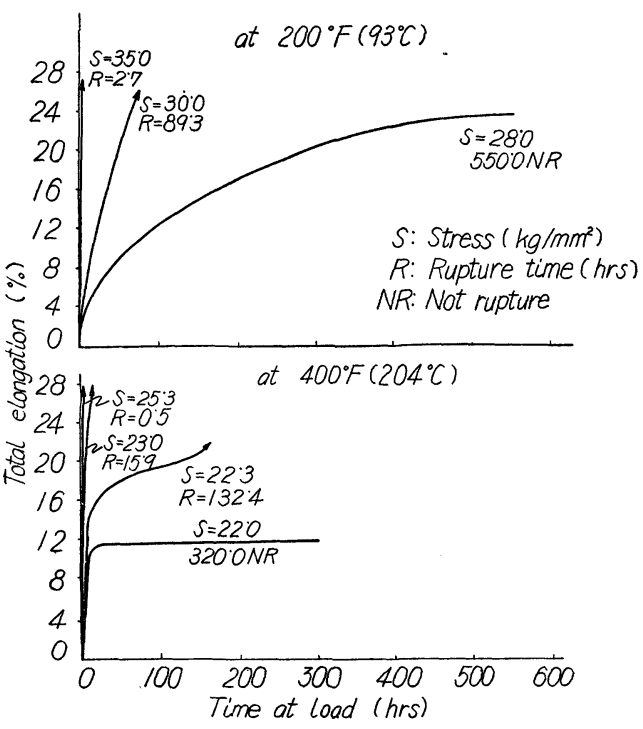

Fig. 4-1. Creep rupture curves at 200 and $400^{\circ} \mathrm{F}\left(93\right.$ and $204^{\circ} \mathrm{C}$ )

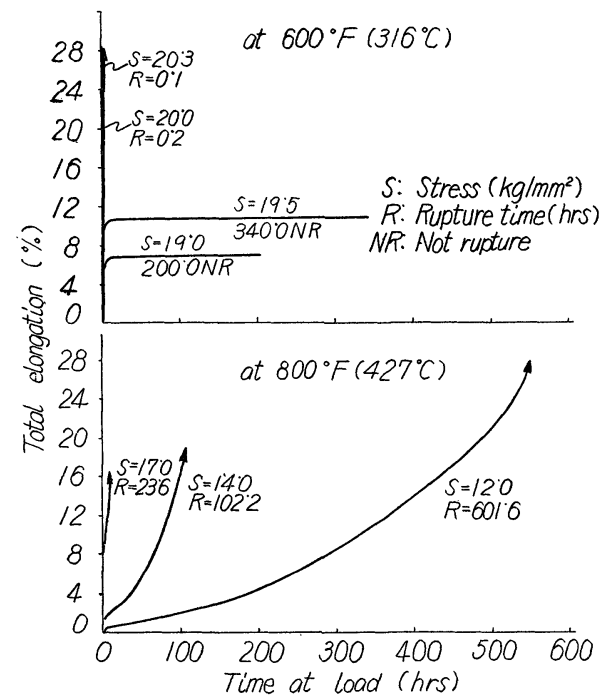

Fig. 4-2. Creep rupture curves at 600 and $800^{\circ} \mathrm{F}\left(316\right.$ and $\left.427^{\circ} \mathrm{C}\right)$

の結果をそれぞれ応力一破断時間扣よび応力一最小ク リープ速度の両対数軸にとって表わしたもので, Fig. 5 から $200^{\circ} \mathrm{F}\left(93^{\circ} \mathrm{C}\right)$ では, 約 100 時間亡での破断時 間では，破断時間飞対する応力の下がりが急激である が，約 100 時間以上ではこの傾斜がきわめてゆるくな

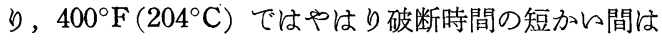
この傾斜がある程度認められるが，約10時間以上では ほとんど認められず， $600^{\circ} \mathrm{F}\left(316^{\circ} \mathrm{C}\right)$ ではさらに短時 間からほとんど破断時間軸に平行になる傾向にある。 $800^{\circ} \mathrm{F}\left(427^{\circ} \mathrm{C}\right)$ では，乙れとは逆に約 10 時間までの破 断時間では，応力の下がりがわずかであるが，それ以
上の破断時間では，破断時間が長くなるにつれ，急激 に応力が下がっ傾向が認められた。また，最小クリ一 プ速度に対する応力の下がりも Fig. 6 から各温度に対 する同じ傾向が認められた。

Fig. 5 から各試験温度について 10，100および 300 時間で破断すべき応力，すなわち $10 ， 100$ 和よび 300 時間破断強度を内雨ある々は外插によって求め, 応力 一試験温度軸に対して高温抗張力和よび 0.2 パーセン 卜耐力と比較して示すと Fig.7 のどとくなる．との図 から $400-600^{\circ} \mathrm{F}\left(204-316^{\circ} \mathrm{C}\right)$ の温度籁团で，クリー

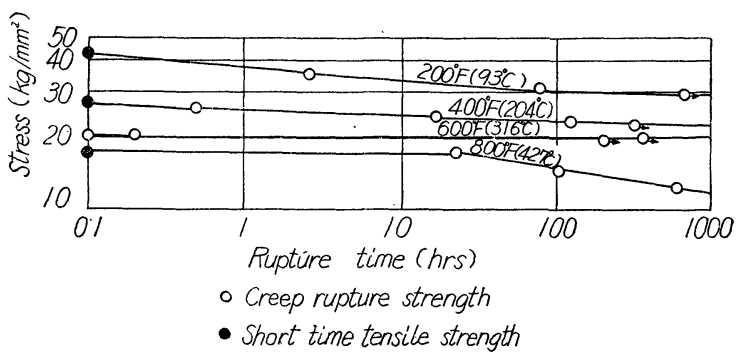

Fig. 5. Stress rupture time curves.

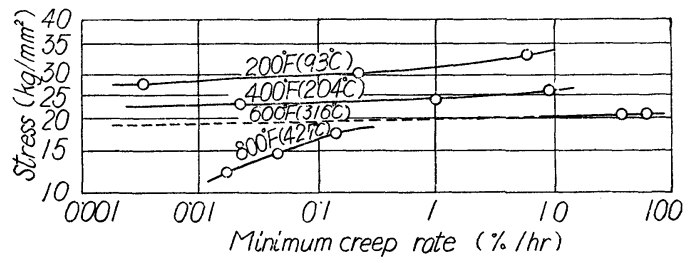

Fig. 6. Stress minimum creep rate curves.

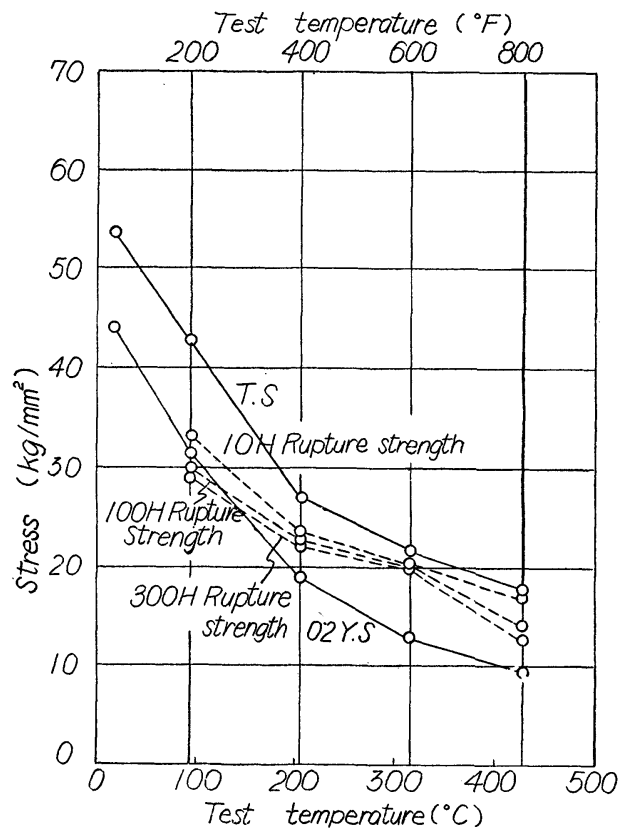

Fig. 7. Rupture strength-temperature curves. 
プ破断強度曲線の試験温度上昇による下がり勾配が高 温抗張力拉よび 0.2 パーセント耐力の下がり公配に比 し，きわめてゆるやかであるととが認められる。しか も破断時間が長時間になる活ど，この曲線のゆるやか な公配が上記試験温度範围飞特異の現象である傾向が 強く見られる。

この現象をさらに検討するために，まず，その原因 として，(1) 歪硬化に伴う現象（本チタニウム材は Fig. 7 にも示しれよらに，特にこの温度簌囲で 0.2 パーセント耐力以上の応力で長時間耐えらる特性を有 するので, 歪硬化に伴ら現象が考えられる.) (2)析 出硬化現象(C,N その他の微量元素が，乙の温度箶团 で析出物を形成するための硬化現象が考えられる。)

(3)酸化による硬化現象（この温度範囲で, 酸素が表 面滲透して酸化物を形成するための硬化現象が考え られる。）空考えてみえ，実験方法として，ます（1） クリープ破断試験前後の硬度顕微鏡組織を調べ, 次に (2)クリープ破断試験結果から, 第二期クリープ如よ び第三期クリープの始まる時間に和ける伸びならびに 中止試料につ々ては中止直前の伸びから，その時間に 斿ける真応力を求め, さらに (3) 400 和よび $600^{\circ} \mathrm{F}$ (204 および $316^{\circ} \mathrm{C}$ ) の試験温度で中止した試験片につ き, 試験前後の酸素和よび水素量ならびに試験中止後 $700^{\circ} \mathrm{C} \cdot 1 \mathrm{Hr}$ 真空焼鈍して硬度を測定した。乙れらの 結果を Table 3-5 に示した。

Table 3 からクリープ破断試験前後の硬度が試験前 に比してV.H.N.で約 10〜35 硬化されているととが認
一められそ。クリープ破断試験に和にて少なくとも第三 期クリープ開始までは局部的収縮が起らないと仮定し， 第二期クリープ開始時, 第三期クリープ開始時ふよび 試験中止した試験片につくては, 中止時の全伸び量か ら試験片の標点間の体積が一定であるとして, その時 の真応力を計算してみを. Table 4 はこれらの結果で ある. Table 4 中 (2-1), (3-1) 执よ゙ (4)-1) と示 Table 3. Hardness before or after rupture test.

\begin{tabular}{|c|c|c|c|c|}
\hline & Test temp. & Test load & V.I & A.N. \\
\hline & $\left({ }^{\circ} \mathrm{F}\left({ }^{\circ} \mathrm{C}\right)\right)$ & $\left(\mathrm{kg} / \mathrm{mm}_{2}\right)$ & $\begin{array}{l}\text { Cenier of } \\
\text { specimen }\end{array}$ & $\begin{array}{c}\text { End of } \\
\text { specimen }\end{array}$ \\
\hline \multicolumn{3}{|c|}{ before test } & 173 & 173 \\
\hline \multirow{13}{*}{$\begin{array}{c}\text { After } \\
\text { test }\end{array}$} & \multirow{3}{*}{$\begin{array}{l}200 \\
(93)\end{array}$} & $35 \cdot 0$ & 208 & 183 \\
\hline & & $30 \cdot 0$ & 207 & 174 \\
\hline & & $28 \cdot 0$ & 196 & 174 \\
\hline & \multirow{4}{*}{$\begin{array}{c}400 \\
(204)\end{array}$} & $25 \cdot 3$ & 202 & 181 \\
\hline & & $23 \cdot 0$ & 204 & 178 \\
\hline & & $22 \cdot 3$ & 210 & 176 \\
\hline & & $21 \cdot 0$ & 185 & 181 \\
\hline & \multirow{3}{*}{$\begin{array}{c}600 \\
(316)\end{array}$} & $20 \cdot 3$ & 208 & 178 \\
\hline & & $20 \cdot 0$ & 205 & 173 \\
\hline & & $19 \cdot 5$ & 193 & 176 \\
\hline & \multirow{3}{*}{$\begin{array}{c}800 \\
(427)\end{array}$} & $17 \cdot 0$ & 207 & 177 \\
\hline & & $14 \cdot 0$ & 200 & 179 \\
\hline & & $12 \cdot 0$ & 201 & 175 \\
\hline
\end{tabular}

Table 4. True stress at the begining of secondary and tertiary creep and at the stop of test.

\begin{tabular}{|c|c|c|c|c|c|c|c|c|c|c|c|c|c|}
\hline \multirow{2}{*}{$\begin{array}{c}\text { Test } \\
\text { temp. } \\
\left({ }^{\circ} \mathrm{F}\left({ }^{\circ} \mathrm{C}\right)\right)\end{array}$} & \multirow{2}{*}{$\begin{array}{c}\text { (1) } \\
\text { Test } \\
\text { stress } \\
\left(\mathrm{kg} / \mathrm{mm}^{2}\right)\end{array}$} & \multicolumn{4}{|c|}{$\begin{array}{l}\text { At the begining of } \\
\text { secondary creep }\end{array}$} & \multicolumn{4}{|c|}{$\begin{array}{l}\text { At the begining of } \\
\text { tertiary creep }\end{array}$} & \multicolumn{4}{|c|}{ At the stop of test. } \\
\hline & & $\begin{array}{l}\text { Time } \\
\text { (hrs) }\end{array}$ & $\begin{array}{c}\text { Total } \\
\text { elong } \\
(\%)\end{array}$ & $\mid \begin{array}{c}\text { 2) } \\
\text { True } \\
\text { stress } \\
\left(\mathrm{kg} / \mathrm{mm}^{2}\right)\end{array}$ & $\begin{array}{c}\text { (2)-(1) } \\
\left(\mathrm{kg} / \mathrm{mm}^{2}\right)\end{array}$ & $\begin{array}{l}\text { Time } \\
(\mathrm{hrs})\end{array}$ & $\begin{array}{l}\text { Total } \\
\text { elong } \\
(\%)\end{array}$ & $\begin{array}{c}\text { (3) } \\
\text { True } \\
\text { stress } \\
\left(\mathrm{kg} / \mathrm{mm}^{2}\right)\end{array}$ & $\begin{array}{c}(3)-1 \\
\left(\mathrm{~kg} / \mathrm{mm}^{2}\right)\end{array}$ & $\begin{array}{l}\text { Time } \\
\text { (hrs) }\end{array}$ & $\begin{array}{c}\text { Total } \\
\text { elong } \\
(\%)\end{array}$ & $\begin{array}{c}\text { T) } \\
\text { True } \\
\text { stress } \\
\left(\mathrm{kg} / \mathrm{mm}^{2}\right)\end{array}$ & $\begin{array}{c}\text { (4)-(1) } \\
\left(\mathrm{kg} / \mathrm{mm}^{2}\right)\end{array}$ \\
\hline \multirow{3}{*}{$\begin{array}{l}200 \\
(93)\end{array}$} & $35 \cdot 0$ & 0.5 & $6 \cdot 8$ & $37 \cdot 4$ & $2 \cdot 4$ & $1 \cdot 1$ & $10 \cdot 8$ & $38 \cdot 8$ & $3 \cdot 8$ & - & - & - & - \\
\hline & $30 \cdot 0$ & 50 & $20^{\circ} 0$ & $36^{\circ} 0$ & $6 \cdot 0$ & 75 & $26^{\circ} 0$ & $37 \cdot 8$ & $7 \cdot 8$ & - & - & - & - \\
\hline & $28 \cdot 0$ & 410 & $22 \cdot 8$ & $34 \cdot 4$ & $6 \cdot 4$ & - & - & - & - & 550 & $23 \cdot 4$ & $34 \cdot 6$ & $6 \cdot 6$ \\
\hline \multirow{4}{*}{$\begin{array}{c}400 \\
(20.4)\end{array}$} & $25 \cdot 3$ & - & $12 \cdot 7$ & $28 \cdot 5$ & $3 \cdot 2$ & 0.2 & $14 \cdot 8$ & $29 \cdot 3$ & $4 \cdot 0$ & - & - & - & - \\
\hline & $23 \cdot 0$ & 7 & $18 \cdot 9$ & $27 \cdot 3$ & $4 \cdot 3$ & 11 & $23 \cdot 3$ & $28 \cdot 4$ & $5 \cdot 4$ & - & - & - & - \\
\hline & $22 \cdot 3$ & 55 & $18 \cdot 9$ & $26 \cdot 5$ & $4 \cdot 2$ & 105 & $20 \cdot 1$ & $26 \cdot 8$ & $4 \cdot 5$ & - & - & - & - \\
\hline & $22 \cdot 0$ & 20 & $11 \cdot 4$ & $24 \cdot 5$ & $2 \cdot 5$ & - & - & - & - & 320 & $11 \cdot 5$ & $24 \cdot 6$ & $2 \cdot 6$ \\
\hline \multirow{4}{*}{$\begin{array}{l}6 C 0 \\
(316)\end{array}$} & $20 \cdot 3$ & $1.5 \mathrm{~min}$ & $19 \cdot 3$ & $24 \cdot 2$ & $3 \cdot 9$ & $2 \cdot 5 \mathrm{~min}$ & $20 \cdot 4$ & $24 \cdot 2$ & $4 \cdot 2$ & - & - & 一 & - \\
\hline & 20.0 & $5 \mathrm{~min}$ & $13 \cdot 0$ & $22 \cdot 6$ & $2 \cdot 6$ & $8.5 \mathrm{~min}$ & $15 \cdot 3$ & $23 \cdot 1$ & $3 \cdot 1$ & - & - & - & - \\
\hline & $19 \cdot 5$ & 10 & $10 \cdot 6$ & $21 \cdot 6$ & $2 \cdot 1$ & - & - & 一 & - & 340 & $10 \cdot 9$ & $21 \cdot 7$ & $2 \cdot 2$ \\
\hline & $19 \cdot 0$ & 15 & $7 \cdot 0$ & $20 \cdot 3$ & $1 \cdot 3$ & - & - & - & - & 200 & $7 \cdot 1$ & $20 \cdot 4$ & $1 \cdot 4$ \\
\hline \multirow{3}{*}{$\begin{array}{l}800 \\
(427)\end{array}$} & $17 \cdot 0$ & 2 & $8 \cdot 5$ & $18 \cdot 5$ & $1 \cdot 5$ & 10 & $10 \cdot 7$ & $18 \cdot 8$ & $1 \cdot 8$ & - & - & 一 & - \\
\hline & $14 \cdot 0$ & 5 & $2 \cdot 3$ & $14 \cdot 3$ & $0 \cdot 3$ & 50 & $3 \cdot 3$ & $14 \cdot 5$ & 0.5 & - & - & - & - \\
\hline & $12 \cdot 0$ & 10 & 0.6 & $12 \cdot 1$ & 0.1 & 110 & $2 \cdot 4$ & $12 \cdot 3$ & 0.3 & - & - & - & - \\
\hline
\end{tabular}


Table 5. Oxygen and hydrogen content before or after creep test and hardness before or after creep test and after vacuum annealing.

\begin{tabular}{|c|c|c|c|c|c|c|c|}
\hline \multirow{2}{*}{ Material } & \multicolumn{2}{|c|}{$\mathrm{O}_{2}(\%)$} & \multicolumn{2}{|c|}{$\mathrm{H}_{2}(\%)$} & \multicolumn{3}{|c|}{$\begin{array}{l}\text { V.H.N. } \\
\text { (Center of specimen) }\end{array}$} \\
\hline & $\begin{array}{l}\text { before } \\
\text { creep test }\end{array}$ & $\begin{array}{l}\text { after } \\
\text { creep test }\end{array}$ & $\begin{array}{l}\text { before } \\
\text { creep test }\end{array}$ & $\begin{array}{l}\text { after } \\
\text { creep test }\end{array}$ & $\begin{array}{l}\text { before } \\
\text { creep test }\end{array}$ & $\begin{array}{l}\text { after } \\
\text { creep test }\end{array}$ & $\begin{array}{c}\text { after } \\
\text { vacuum } \\
\text { annealing }\end{array}$ \\
\hline $\begin{array}{l}400 \mathrm{~F}(204 \mathrm{C}), 21 \cdot 0 \mathrm{~kg} / \mathrm{mm}^{2} \\
430 \mathrm{H} \text { not rupture }\end{array}$ & 0.110 & 0.125 & 0.0026 & 0.0021 & 173 & 185 & 173 \\
\hline $\begin{array}{l}600 \mathrm{~F}\left(316^{\circ} \mathrm{C}\right), 19 \cdot 5 \mathrm{~kg} / \mathrm{mm}^{2} \\
330 \mathrm{H} \text { not rupture }\end{array}$ & $0 \cdot 110$ & $0 \cdot 100$ & 0.0036 & 0.0029 & 173 & 193 & 173 \\
\hline
\end{tabular}

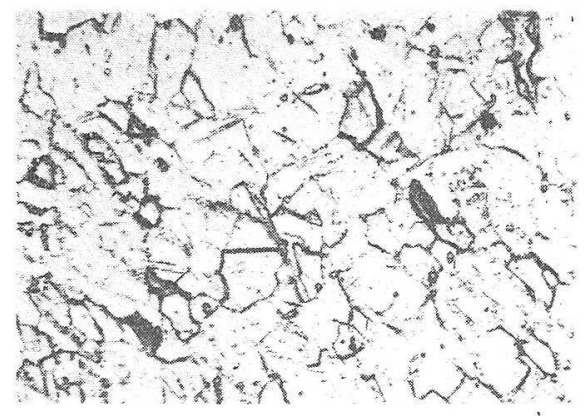

Before test

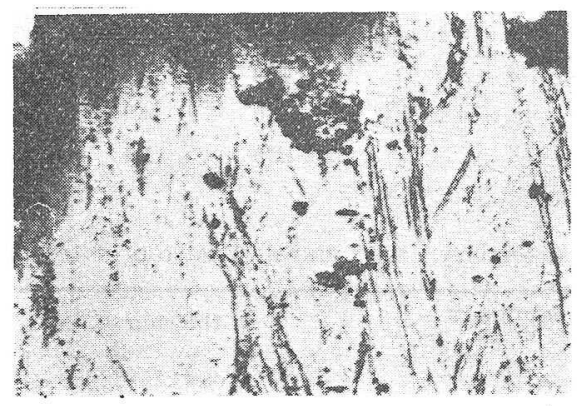

Center of specimen

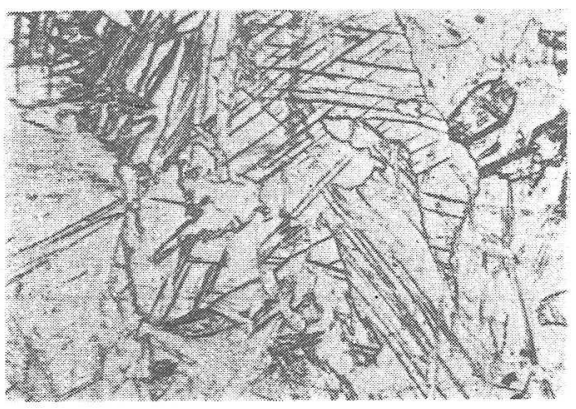

End of specimen

$200^{\circ} \mathrm{F}\left(93^{\circ} \mathrm{C}\right), 35 \cdot 0 \mathrm{~kg} / \mathrm{mm}^{2}, 2 \cdot 7 \mathrm{hrs}$ rupture.

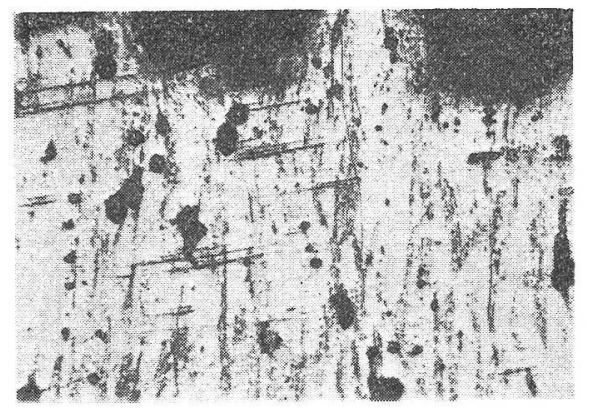

Center of specimen

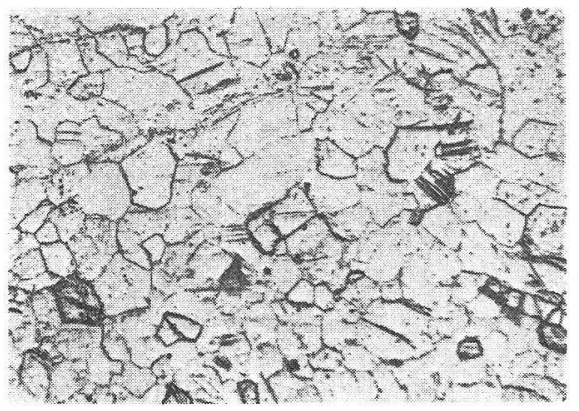

End of specimen

$800^{\circ} \mathrm{F}\left(427^{\circ} \mathrm{C}\right), 12 \cdot 0 \mathrm{~kg} / \mathrm{mm}^{2}, 601 \cdot 6 \mathrm{hrs}$ rupture.

Photo. 1-1. Microstructure before or after creep rupture test. $\left(\mathrm{HNO}_{3}+5 \% \mathrm{HF}\right)$ solu, etch. $(\times 100)$ 


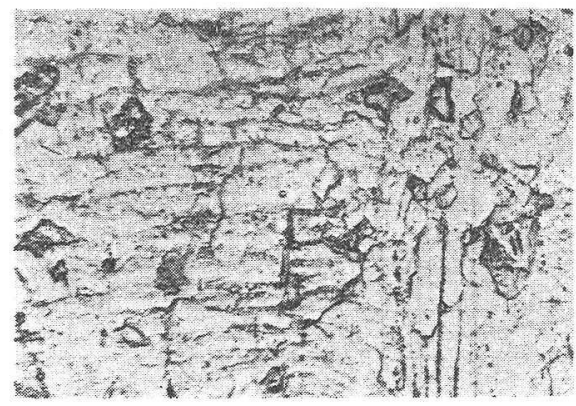

Center of specimen

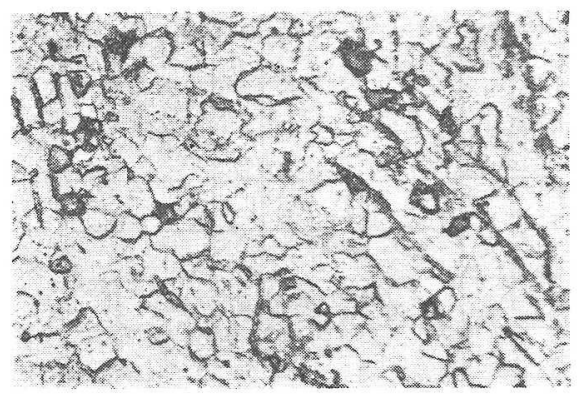

End of specimen

$400^{\circ} \mathrm{F}\left(204^{\circ} \mathrm{C}\right), 21: 0 \mathrm{~kg} / \mathrm{mm}^{2}, 430 \mathrm{hrs}$ not rupture.

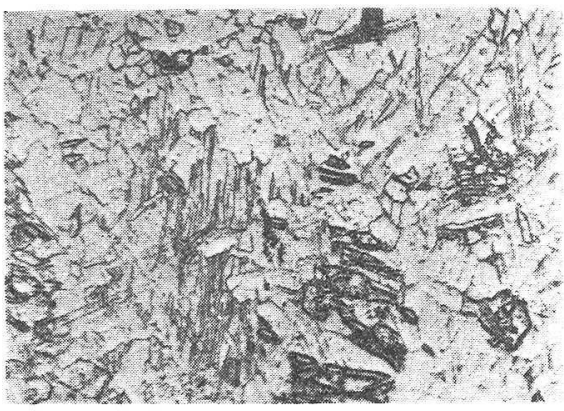

Center of specimen

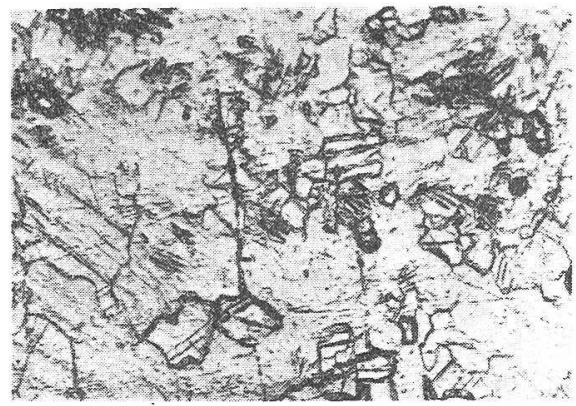

End of specimen

$600^{\circ} \mathrm{F}\left(316^{\circ} \mathrm{C}\right), 19.5 \mathrm{~kg} / \mathrm{mm}^{2}, 330$ hrs not rupture.

Photo. 1-2. Microstructure after creep test $\left(\mathrm{HNO}_{3}+5 \% \mathrm{HF}\right)$ solu etch. $(\times 100)$

しれ応力は，それぞれ第二期クリープの開始時，第三 期クリープの開始時ふよど破断試験中止時の直応力か ら負荷時の応力起差し引いそ值で，各時期で傎荷時の 応力よりこの值行け多く堪えていたこと肴してい る。ここで注目すべきととな，試験中止試料の中止時

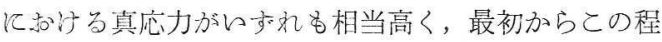
度の荷重をかければ，い和れも非常に短時閒で破断す る応力であることである。Table 5 は 400 Jっよど $600^{\circ} \mathrm{F}$ (204 ふよど $316^{\circ} \mathrm{C}$ ) のクリープ破断試験中止試料につ らて, 試験前後の酸素ふよび水素量ならじに試験前後

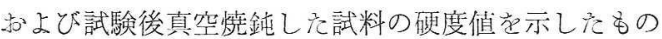
で, 酸素扣よど水素量は质とんど变化なく, 硬度も真 空焼鈍を行らと試験前と同一値になるととが認められ た。とのととは，との温度範囲における硬化現象が酸 化によるものではないと想像される。Fig. 8 はクリー プ破断試験前後の頙微鏡組織を試験片中心部抽よび末 端ネジ部につ々てその代表的数例示したものであ る。中心部の組織は，破断して試料につ々ては破断位 置, 他は平行部中心位置のいずれも引張方向の写真で ある。まそ，末端ネジ部についても中心部と同じ方向 の組織を示してある。破断付近の組織は，らすれも引 張方向に組織が繊維状に伸ばされ，多くの引きちきら
れて生じた空孔が認められる。試験中止試料の中心部 およびすべての末端ネジ部（ネジ部も多少応力がかか る）は，引張応力によって生じたすべり，あるいは双 晶と思かれるものがか交り認好られれが，析出物につ らてな 1000 倍程度に倍率上上げても明かでなかっ ic.

\section{5. 考察}

Fig. 8 おとど Fig. 9 は文献より引用しそ99.2 パー セント Ti 尭鈍チ夕ニウムシートのクリープ試験結果 である。Fig. 9 と Fig. 5 を比較すると，とも同一 の傾向がある。す交わら， $400^{\circ} \mathrm{F}\left(204^{\circ} \mathrm{C}\right)$ の曲線が病 とんど横嵮に平行で，その上下の温度では傾斜が急て ある.Fjg. 8 中の 0.0001\%/Hr の最小クリープ速度 起生ず応力は $400^{\circ} \mathrm{F}\left(204^{\circ} \mathrm{C}\right)$ 付近で最高在生でてい 3.とのととは，Fig. 7 中で 10，100，300 時間破断

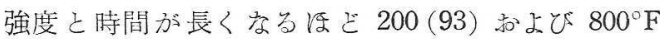

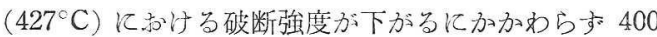
ふよび $600^{\circ} \mathrm{F}\left(204\right.$ 叔よど $\left.316^{\circ} \mathrm{C}\right)$ の破断強度が在とえ ご下がらない傾向をより顕著に示しているものと思わ れる。すなわち，Fig. 6 亿おいて風中の試験よりさら

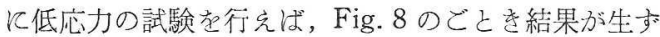
るものと考完られる。 


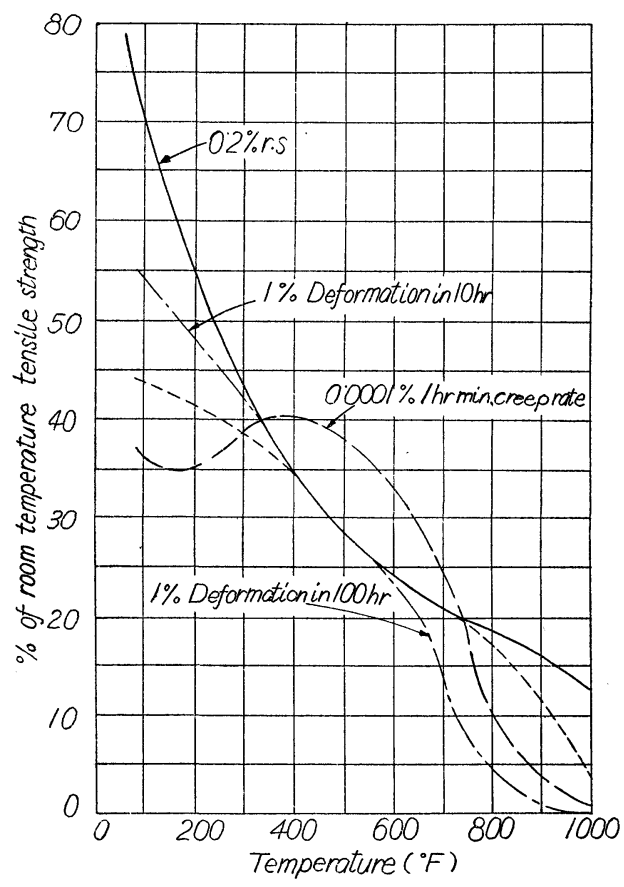

Fig. 8. Creep properties of annealed titanium sheet $(99 \cdot 2 \mathrm{Ti})$.

このよらな現象に対して現在までは歪硬化に伴ら現 象であるといら推測が最も有力視されているが, 析出 硬化に対しては 1000 倍程度の倍率に上げても判定困 難であるので，な沶今後の研究に待たねばならないと 考えられる、酸化による硬化現象は，(1)試験前後の 酸素量がほとんど変化しないとと.（2)試験後真空焼 鈍するととにより, 試駼前の硬度に帰るととから, 酸 化現象は関係ないと思わ礼る。

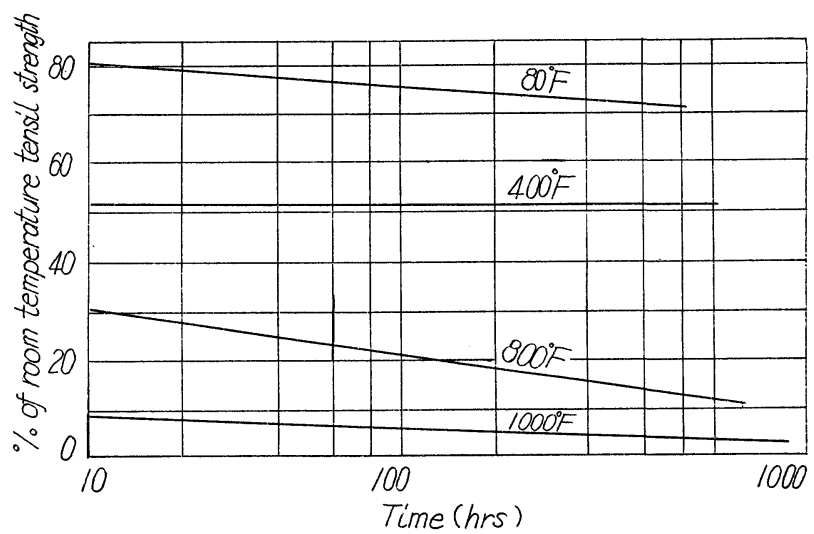

Fig. 9. Creep rupture curves for annealed Titanium sheet (99.2 2 Ti).

6. 結

\section{言}

消耗電極式再溶解法により工業用純チタニウム $\mathrm{KS}$ -70 の鋳塊を溶製し, その真空焼鈍材について 200一 $800^{\circ} \mathrm{F}\left(93-427^{\circ} \mathrm{C}\right)$ でクリープ破断試験を行々, 高温 短時間引張試験による強度の温度勾配が, $400-600^{\circ} \mathrm{F}$ $\left(204-316^{\circ} \mathrm{C}\right)$ でゆるやかになる傾向が, クリープ破 断強度ではより顕著にあらわれるとと省確認した。 の原因として, 歪硬化および工業用純チタニウム中に 少量含まれる不純物にもとづく析出硬化が考えられる が，乙れは今後の研究に待たねば明らかに断定しえな かった。しかし，酸化による硬化現象でないことは， ガス分析, 硬度測定試験の結果から確認された。

注: -

1) The ASM Comittee on Titanium, Metal Progress, July 15 , pp. $80 / 89$ (1954)

2) D.R. Luster. W.W. Wentz and D.W. Kaufmann, Materials and Methods, Vol. 37, No.6, pp. 100/103 (1953)

3) W.R. Kiessel and M.J. Sinnott, Transactions AlME. pp. $331 / 338$ (1953)

(39頁より)

Autographic Bearing-Strength Test and Typical Test Values on Some Magnesium Alloys at Room and Elevated Temperatures, A.A. Moore and James A. Gusack

室温和よび高温における数種のマグネシウム合金の自記耐圧強度試験及び試験結果

Evaluation of Test Variables in the Determination of Shear Strength, R.W. Fenn, Jr., and R.B. Clapper

\section{剪断強度决定の擦の試験条件の評価}

Creep-Rupture Tests in Shear of Cast Antimony-Lead Alloys, J. Neil Greenwood

鋳造アンチモ二鉛合金の剪断クリープ破断試験

The Corrosion Properties of Chromium-Nickel-Manganese Austenitic Stainless Steels, W.G. Renshaw and R.A. Lula

クロム・ニッケル・マンガン・オーステナイト不銹鋼の腐蝕特性

(48頁へつづく) 